\title{
Comparative Growth Performance, Carcass Characteristics and Meat Quality of Local Horro and Exotic Cockerels of Tropical Origin Fed Growers Diet
}

\author{
Abrar Biazen ${ }^{*}$, Urge Mengistu ${ }^{1}$, Ameha Negassi', Aseffa Getenet ${ }^{2}$, \\ Abegaz Solomon ${ }^{3}$, Dessie Tadelle ${ }^{4}$ \\ ${ }^{1}$ School of Animal and Rangeland Sciences, Haramaya University, Haramaya, Ethiopia \\ ${ }^{2}$ Land O'Lakes, Addis Ababa, Ethiopia \\ ${ }^{3}$ Ethiopian Institute of Agricultural Research, Addis Ababa, Ethiopia \\ ${ }^{4}$ International Livestock Research Institute, Addis Ababa, Ethiopia \\ Email: ^bizabr@gmail.com
}

How to cite this paper: Biazen, A., Mengistu, U., Negassi, A., Getenet, A., Solomon, A. and Tadelle, D. (2021) Comparative Growth Performance, Carcass Characteristics and Meat Quality of Local Horro and Exotic Cockerels of Tropical Origin Fed Growers Diet. Open Journal of Animal Sciences, 11, 62-83.

https://doi.org/10.4236/ojas.2021.111006

Received: November 16, 2020

Accepted: January 25, 2021

Published: January 28, 2021

Copyright $\odot 2021$ by author(s) and Scientific Research Publishing Inc. This work is licensed under the Creative Commons Attribution International License (CC BY 4.0).

http://creativecommons.org/licenses/by/4.0/

\begin{abstract}
Growth performance, carcass characteristics and meat quality of male chickens were evaluated using eight-week-old 360 cockerels from three exotic (Koekoek, Kuroiler and Sasso-R) and one Ethiopian indigenous (Horro) genotypes. Cockerels in each breed (90) were randomly allocated into three replications of 30 birds each and housed in deep litter pens for the experiment that lasted for 8 to 16 weeks. The experiment was arranged in a Completely Randomized Design. Seven birds per breed were slaughtered at the end to determine carcass yield, chemical composition and quality attributes of meat. The Kuroiler breed has higher body weight, body weight change (1621.8 g), average daily gain $(28.9 \mathrm{~g} /$ day $)$, daily feed consumption $(127.4 \mathrm{~g} /$ day $)$ and better feed conversion ratio (4.40) than other breeds. The Kuroiler breed has heavier slaughter weight $(2716.3 \mathrm{~g})$, dressed carcass weight $(2201.0 \mathrm{~g})$, eviscerated carcass weight $(1905.1 \mathrm{~g})$, breast weight $(537.7 \mathrm{~g})$, thigh weight $(303.1 \mathrm{~g})$ and drumstick weight $(274.8 \mathrm{~g})$ than other breeds. Total edible offal was higher for Kuroiler (324.2 g) and Sasso-R (306.1 g), intermediate in Koekoek (204.4 g) and low in Horro (152.4 g) breed. The relative proportion of breast and drumstick (\% slaughter weight) were lower in Koekoek and Sasso-R (17.3 and 8.9 ) breeds, respectively. Abdominal fat weight (13.7 $\mathrm{g}$ and $1.02 \%)$ was lowest in Horro. Sasso-R showed higher percent edible offal weight (13.4\%) than Horro breed (11.4\%). The DM content in breast and thigh meat was higher for Horro breed than the rest. The CP content in the breast and thigh
\end{abstract}


meat was lower for the Kuroiler and Koekoek breeds, respectively. Higher EE in the thigh meat was recorded for Sasso-R (8.9\%), whereas, EE content in the breast meat was similar (3.4\% - 3.7\%) among the breeds. Flavor, tenderness, juiciness and general acceptability of breast and thigh meat were not affected by breed. The highest net return was observed in the Kuroiler breed. Based on the results obtained, it is suggested that the Kuroiler breed can be used for cockerel meat production in Ethiopia where intensive broiler production is not well developed.

\section{Keywords}

Breed, Carcass Characteristics, Chicken, Cockerel, Growth, Meat Quality

\section{Introduction}

The per capita consumptions of chicken meat and egg (kg/person/year) in Ethiopia is 0.66 and 0.36 which is equivalent to 73931 and 52161 tonnes of national production, respectively [1]. Meat and egg consumption figures are much lower than the report for Uganda (0.97 and 5.1). Similarly, the annual growth rate of chicken meat and egg production per year between 2014 and 2018 in Ethiopia $(1.5 \%$ and $2.2 \%)$ is lower than the growth recorded by neighboring Kenya $(2.9 \%$ and 5.3\%) [1] [2]. The low total production as well as the production per person per year shows the need to increase the supply of poultry meat and egg. In Ethiopia, three types of chicken namely indigenous, hybrid and commercial exotic are kept for meat and egg production with a total estimated population of about 56.1 million [3] mainly comprising indigenous breeds. The adaptability of indigenous chickens to low-input management systems enables them to fulfill their role in providing nutrition and income to the rural households. However, they have limited genetic capacity for egg and meat production when compared to exotic breeds. Indigenous birds reared under backyard system attain a body weight of 714.4 and $865.5 \mathrm{~g}$ at 16 and 18 weeks of age, respectively [4] and produce 66.5 eggs per bird per year [5]. The low production potential of local chickens has resulted in the demand for birds with better productivity and suitability to the village production environment. However, the shortage of adequate supply of locally available productive strains or breeds has been an obstacle to boost production in developing countries. Chicken stocks developed by global operation breeding companies are less fit to the common backyard production system. Some companies have recently developed dual purpose chickens that combine higher meat and egg production and better adaptability [6] [7]. The Ethiopian Agricultural Research Institutes and private sector in the country came up with improved and crossbred chicken genotypes such as Horro and Sasso-RIR [5] [8].

Over the years, various exotic breeds of chickens have been introduced to improve productivity. However, improvement options built on imported genetic 
material (chicken genotype) may not be sustainable. Therefore, the production of improved stocks locally, remains the only way to build a strong and viable poultry sector in Ethiopia. To address this challenge, efforts were made by African Chicken Genetic Gain (ACGG) to improve the supply of improved breeds in Africa, mainly dual-purpose breeds. The use of dual-purpose chicken breeds will offer an opportunity to utilize males for meat production in areas where intensive broiler production is not well developed. Moreover, the management of egg-type male chickens is easier than broilers particularly in rural areas where modern rearing facilities and high quality poultry feeds are not available. However, to effectively utilize the special features of the breeds, there is a need to improve the production environment.

The major economic traits in chicken used for meat production includes body weight, growth rate, carcass traits, chemical composition and sensory attributes of meat. Several factors including breed have been shown to affect these traits in poultry [9] [10] [11]. However, performance evaluation studies of indigenous and tropical adapted exotic dual purpose breeds under similar on-station management are scanty. Therefore, the present experiment was initiated to assess growth performance, carcass characteristic, chemical composition and sensory attribute of meat in Horro, Koekoek, Kuroiler and Sasso-R crossbred cockerels raised from 8 - 16 weeks of age under intensive management systems with optimum feeding, housing, biosecurity and health measures in Ethiopia.

\section{Materials and Methods}

\subsection{Study Site, Breeds and Management of Birds}

The study was conducted at Haramaya University poultry farm, Ethiopia. The farm is located at $42^{\circ} 3^{\prime} \mathrm{E}$ longitude, $4^{\circ} 26^{\prime} \mathrm{N}$ latitude and at an altitude of 1980 meter above sea level. Three exotic (Koekoek, Kuroiler and Sasso-R) and one indigenous (Horro) chicken breeds were used for this study. The breeds were identified by the African Chicken Genetic Gain (ACGG) project for genetic improvement in Ethiopia. The breeds were selected based on their suitability in low input tropical poultry production systems [6]. The Koekoek is a noncommercial composite breed developed in South Africa through crossing White leghorn, Black Australorp and Bared Plymouth Rock breeds [12]. The Kuroiler is a hybrid chicken developed by a commercial breeding company in India (Kegg farm) for village production [6]. The Sasso-RIR is F1 crossbreed chicken (Sasso hen and RIR cocks) by Ethio-chicken private company in Ethiopia [8]. The Horro is a local chicken breed that has been selected for about seven generations to improve survival and productivity [5].

All birds in each breed were received as straight run day old chicks from the hatchery at Debre Zeit Agricultural Research Center. Since the sex differentiation of day-old chicks was not possible, mixed sex rearing were followed during the brooding period ( 0 - 8 weeks). After sex separation, a total of 360 cockerels from the four breeds ( 90 birds each) were transferred to the male grower's pens 
and used for the experiment. Birds in each breed were randomly divided into three groups (replication) and assigned to a deep litter pen. Poultry houses and equipment (drinkers and feeders) were properly cleaned and disinfected before the placement of cockerels. Birds were fed the same grower diet which contained maize grain $(55 \%)$, wheat short $(17 \%)$, soybean meal $(10 \%)$, peanut seed cake $(10 \%)$, Noug seed cake (6\%), lime stone (1\%), vitamin premix (0.7) and salt $(0.3 \%)$. All birds received fresh and clean drinking water at all times. All the experimental birds were vaccinated against Newcastle at day 63 and 112, Fowl pox at day 72 and Typhoid at day 84 . Routine bio-security measures were taken throughout the experimental period.

\subsection{Measurements}

Feed consumption for each day was recorded as the difference between the amount of feed offered and refusals. Total feed consumption (TFC) and daily feed consumption (DFC) per bird on pen basis was determined for the entire experimental period. Total feed consumption was calculated by dividing feed consumption by average number of birds in each replicate. The DFC was determined by dividing total feed consumption by the number of experimental days. Body weight $(\mathrm{BW})$ of birds in each pen was recorded at 8,10,12, 14 and 16 weeks of age on individual basis. The average BW was calculated by dividing total body weight in each pen by the number of birds. Body weight changes (BWC), average daily gain (ADG) and feed conversion ratio (FCR) were determined for the entire experimental period. Body weight change was calculated as the difference between the final and initial BW. The ADG was calculated as BWC divided by the number of experimental days. Feed conversion ratio was calculated as the amount of feed consumed divided by body weight gain. Mortality was registered as it occurred and general health status was monitored throughout the experiment. Percent mortality was calculated for the entire experimental period as the proportion of birds that died to the number of birds at the beginning of the experiment multiplied by 100 .

Carcass traits were evaluated at the end of 16 weeks using seven birds randomly selected per pen that is a total of 28 per treatment. Selected birds from each replication were deprived off feed overnight and slaughtered. Birds were placed in a bleeding cone and killed by severing the neck with a sharp knife. The birds were weighed 120 second after neck cutting and after hand de-feathering to determine blood weight (BW) and feather weight (FW) by difference, respectively. The dressed carcass weight (DCW) was determined after bleeding, defeathering and removal of head and shank. Eviscerated carcass weight (ECW) was determined after the removal of nonedible viscera. The eviscerated carcasses were then cut into six parts namely, breast, thigh, drumstick, wings, neck and back to determine their weight. The edible offal which includes liver, heart, gizzard and skin were weighed. Fat around the proventriculus and gizzard and against the abdominal wall and the cloacae were collected and 
weighed. The proportion of dressed and eviscerated carcass, carcass cut parts, edible offal and non-edible offal were expressed as percentage of body weight at slaughter.

Chemical analysis (moisture, crude protein, ether extract, and ash contents) and determination of meat quality attributes (tenderness, juiciness, flavor and general acceptability) of both breast and thigh meat were conducted at the university laboratories. The proximate compositions were determined in duplicate according to the Association of Official Analytical Chemists procedure [13]. Sensory evaluation of roasted meat was carried out by 8 panelist using a 7 -point scale score card in which the highest score of 7 being extremely tender, juicy, desirable and liked and the least score of 1 is extremely tough, dry, undesirable and unlikable.

Partial budget analysis was performed to evaluate the profitability of raising different breeds of cockerels for meat production by considering the main cost components of production such as feed, vaccine and labor. To calculate the feed cost for each breed, the proportion of ingredients included in the diet and the costs of feed ingredients were used. Vaccination cost was calculated by multiplying the number of vaccines per bird by price of a single dose. Total labor cost was divided by the number of birds to determine labor cost per bird. Total return (TR) was obtained by multiplying the average meat yield (weight of carcass parts and edible offal) by the current price of poultry carcass in the supermarket. The difference in TR and total variable cost was considered as net (NR) in the analysis. The calculation was done according to [14].

\subsection{Statistical Analysis}

Data were analyzed using the General Linear Models (GLM) procedure of SAS 9.4 software [15] with the model containing breeds as dependent variable. The means for breeds showing significant difference in the analysis of variance were compared by Tukey Kramer Test. The means were considered significant at $\mathrm{P}<$ 0.05 for all analyses. The following model was used to analyze the data obtained in this study.

$$
Y_{i j}=\mu+B_{i}+\varepsilon_{i j}
$$

where: $Y_{i j}=$ individual observation; $\mu=$ Over all mean effect; $B_{i}=$ effect of the $\mathrm{i}^{\text {th }}$ breed (1 - 4; Improved local chicken, Koekoek, Kuroiler and Sasso-R); $\varepsilon_{i j}=$ random error.

\section{Results}

\subsection{Body Weight, Body Weight Change and Average Daily Gain}

The result revealed significant $(\mathrm{P}<0.01)$ effect of breed on body weight $(\mathrm{BW})$, body weight change (BWC) and average daily gain (ADG) of birds (Table 1). Significantly heavier BW at 8,10,12,14 and 16 weeks of age was recorded in the Kuroiler breed followed by Sasso-R, whereas Koekoek and Horro exhibited 
Table 1. Body weight, body weight change and average daily gain of different male chicken breeds from 8 - 16 weeks of age.

\begin{tabular}{|c|c|c|c|c|c|c|}
\hline \multirow{2}{*}{ Trait } & \multicolumn{4}{|c|}{ Breed } & \multirow{2}{*}{ SEM } & \multirow{2}{*}{$P$-value } \\
\hline & Ho & Ko & $\mathrm{Ku}$ & Sa-R & & \\
\hline BW8 g & $565.5^{c}$ & $604.5^{c}$ & $1042.5^{\mathrm{a}}$ & $800.1^{\mathrm{b}}$ & 27.14 & $* * *$ \\
\hline BW10 g & $777.2^{c}$ & $798.5^{\mathrm{c}}$ & $1437.8^{\mathrm{a}}$ & $1112.4^{\mathrm{b}}$ & 29.80 & $* * *$ \\
\hline BW12 g & $1014.2^{\mathrm{c}}$ & $1070.9^{c}$ & $1843.8^{\mathrm{a}}$ & $1492.5^{\mathrm{b}}$ & 30.94 & $* * *$ \\
\hline BW14 g & $1221.2^{\mathrm{d}}$ & $1420.2^{c}$ & $2301.1^{\mathrm{a}}$ & $1845.4^{\mathrm{b}}$ & 35.90 & $* * *$ \\
\hline BW16 g & $1416.3^{\mathrm{d}}$ & $1734.4^{\mathrm{c}}$ & $2730.9^{\mathrm{a}}$ & $2136.6^{b}$ & 44.54 & $* * *$ \\
\hline BWC (g/bird) & $808.9^{d}$ & $1078.8^{c}$ & $1621.8^{\mathrm{a}}$ & $1205.0^{\mathrm{b}}$ & 23.32 & $* * *$ \\
\hline $\mathrm{ADG}$ (g/bird) & $14.4^{\mathrm{d}}$ & $19.3^{c}$ & $28.9^{\mathrm{a}}$ & $21.5^{\mathrm{b}}$ & 0.41 & $* * *$ \\
\hline
\end{tabular}

${ }_{\text {a,b,c,d }}$ Means with different superscript letter in a row are significantly different from each other $(\mathrm{p}<0.001)$; $\mathrm{ADG}=$ average daily gain; $\mathrm{BW}=$ body weight; $\mathrm{BWC}=$ body weight change; Ho = Horro; Ko = Koekoek; Ku $=$ Kuroiler; Sa-R $=$ Sasso and Rhode Island Red crossbred; SEM = standard error of the mean.

the lowest. Body weights at 8,10 and 12 weeks were similar between Horro and Koekoek, whereas at 14 and 16 weeks Koekoek breed was significantly heavier than Horro. Greater BWC and ADG $(\mathrm{P}<0.05)$ were recorded in the Kuroiler, while the lowest was observed in Horro breed. The mean BWC and ADG of Sasso- $\mathrm{R}$ crossbred chicken were significantly $(\mathrm{P}<0.05)$ higher than that of Koekoek and Horro breeds.

\subsection{Feed Consumption, Feed Conversion Ratio and Morality of birds}

The dry matter, crude protein, ether extract, total ash, crude fiber, nitrogen free extract and calculated ME kcal $/ \mathrm{kg}$ of the grower diet were 91.7, 17.3, 4.8, 5.8, 4.9, 58.8 and 2821.1, respectively. Crude protein and ME content of the diet are within the recommended range for growers [16]. The Kuroiler exhibited high ( $\mathrm{P}$ $<0.01$ ) total feed consumption and daily feed consumption followed by Sasso-R, Koekoek and Horro. Feed conversion ratio of Horro was significantly higher than all the other breeds followed by Kuroiler, whereas Sasso-R and Koekoek breeds recorded the lowest value. Feed conversion ratio of Horro was significantly higher than all the other breeds followed by Kuroiler, whereas Sasso- $\mathrm{R}$ and Koekoek breeds recorded the lowest value. The highest $(\mathrm{P}<0.05)$ mortality rate was recorded in Kuroiler and Koekoek, while the lowest rate was in Sasso- $\mathrm{R}$ crossbred chicken. The rate of mortality in Horro breed was similar with the other three breeds (Table 2).

\subsection{Slaughter and Dressed Carcass Weight}

Slaughter weight and dressed carcass weight were high $(\mathrm{P}<0.05)$ in Kuroiler followed by Sasso- $\mathrm{R}$ and Koekoek while Horro recorded lower value for these parameters (Table 3). Percent feather weight was high $(\mathrm{P}<0.05)$ in Sasso- $\mathrm{R}$ than in Kuroiler, whereas Horro, Koekoek and Kuroiler did not differ in percent 
Table 2. Total and daily feed consumption feed conversion ratio and mortality of different male chicken breeds from 8 - 16 weeks of age.

\begin{tabular}{|c|c|c|c|c|c|c|}
\hline \multirow{2}{*}{ Trait } & \multicolumn{4}{|c|}{ Breed } & \multirow{2}{*}{ SEM } & \multirow{2}{*}{$P$-value } \\
\hline & Ho & Ko & $\mathrm{Ku}$ & Sa-R & & \\
\hline TFC (g/bird) & $4406.2^{\mathrm{d}}$ & $5445.1^{\mathrm{c}}$ & $7133.8^{\mathrm{a}}$ & $5901.5^{\mathrm{b}}$ & 84.55 & $* * *$ \\
\hline DFC(g/bird) & $78.7^{\mathrm{d}}$ & $97.2^{c}$ & $127.4^{\mathrm{a}}$ & $105.4^{\mathrm{b}}$ & 1.52 & $* * *$ \\
\hline FCR & $5.46^{\mathrm{a}}$ & $5.05^{\mathrm{b}}$ & $4.40^{\mathrm{c}}$ & $4.90^{\mathrm{b}}$ & 0.09 & $* * *$ \\
\hline Mortality (\%) & $4.48^{\mathrm{ab}}$ & $8.89^{\mathrm{a}}$ & $9.86^{\mathrm{a}}$ & $2.30^{\mathrm{b}}$ & 1.32 & * \\
\hline
\end{tabular}

${ }_{\mathrm{a}, \mathrm{b}, \mathrm{c}, \mathrm{d}}$ Means with different super script letter in a row are significantly different ${ }^{* * *}$ when $\mathrm{P}<0.001$; ${ }^{*}$ when $\mathrm{P}$ $<0.05)$; DFC = daily feed consumption; FCR = feed conversion ratio; SEM = standard error of the mean; $\mathrm{TFC}=$ total feed consumption; $\mathrm{PM}=$ percentage mortality; Ho = Horro; Ko = Koekoek; Ku = Kuroiler; $\mathrm{Sa}-\mathrm{R}=$ Sasso and Rhode Island Red crossbred.

Table 3. Slaughter weight, dressed weight and percentage of different male chicken breeds slaughtered at 16 weeks of age.

\begin{tabular}{|c|c|c|c|c|c|c|}
\hline \multirow{2}{*}{ Trait } & \multicolumn{4}{|c|}{ Breed } & \multirow{2}{*}{ SEM } & \multirow{2}{*}{$P$-value } \\
\hline & Ho & Ko & $\mathrm{Ku}$ & Sa-R & & \\
\hline SW (g) & $1334.5^{\mathrm{d}}$ & $1689.3^{c}$ & $2716.3^{\mathrm{a}}$ & $2285.6^{\mathrm{b}}$ & 32.91 & $* * *$ \\
\hline BL (\% SW) & 4.8 & 4.9 & 4.8 & 4.5 & 0.19 & NS \\
\hline FR (\% SW) & $6.9^{\mathrm{ab}}$ & $7.1^{\mathrm{ab}}$ & $6.5^{\mathrm{b}}$ & $8.0^{\mathrm{a}}$ & 0.32 & * \\
\hline H (\% SW) & $3.3^{\mathrm{ab}}$ & $3.8^{\mathrm{a}}$ & $3.2^{\mathrm{ab}}$ & $2.8^{\mathrm{b}}$ & 0.13 & $* * *$ \\
\hline S (\% SW) & $4.5^{\mathrm{b}}$ & $5.1^{\mathrm{a}}$ & $4.5^{\mathrm{b}}$ & $4.0^{c}$ & 0.10 & $* * *$ \\
\hline $\mathrm{DL}^{1}(\% \mathrm{SW})$ & $19.5^{\mathrm{ab}}$ & $20.9^{\mathrm{a}}$ & $19.0^{\mathrm{b}}$ & $19.3^{\mathrm{b}}$ & 0.38 & ** \\
\hline $\mathrm{DC}(\mathrm{g})$ & $1074.5^{\mathrm{d}}$ & $1337.0^{c}$ & $2201.0^{\mathrm{a}}$ & $1844.8^{\mathrm{b}}$ & 2.74 & $* * *$ \\
\hline DC $(\%$ SW $)$ & $80.5^{\mathrm{ab}}$ & $79.1^{\mathrm{b}}$ & $81.0^{\mathrm{a}}$ & $80.7^{\mathrm{a}}$ & 0.38 & $* *$ \\
\hline
\end{tabular}

a,b,c,d Means within a row with different superscript letters are significantly different; ${ }^{* *}=\mathrm{P}<0.001$; ${ }^{* *}=\mathrm{P}<$ 0.01; NS = non-significant; $\mathrm{BL}=$ blood; $\mathrm{DC}=$ dressed carcass $=$ SW-BL-FR-H-S; $\mathrm{DL}^{1}$; Dressing loss $(\mathrm{BL}+$ $\mathrm{FR}+\mathrm{H}+\mathrm{S}) ; \mathrm{FR}=$ feather; $\mathrm{H}=$ head; $\mathrm{S}=$ shank; $\mathrm{SEM}=$ standard error of the mean; $\mathrm{SW}$ = slaughter weight; Ho = improved Horro; Ko = Koekoek; Ku = Kuroiler; Sa-R = Sasso and Rhode Island Red crossbred.

feather weight. Koekoek has high $(\mathrm{P}<0.05)$ percent shank weight than the rest. Horro and Kuroiler recorded similar, but greater $(\mathrm{P}<0.05)$ percent shank weight than Sasso-R. The relative weight of total processing loss (blood + feather + neck + shank) in the Koekoek breed was significantly high than Kuroiler and Sasso-R, but similar $(\mathrm{P}>0.05)$ with Horro. Lower $(\mathrm{P}<0.05)$ percent dressed carcass weight was obtained from Koekoek chicken than Sasso- $\mathrm{R}$ and Kuroiler, while the Horro has similar value with all of the other breeds.

\subsection{Eviscerated Carcass and Edible Offal Weight}

The Kuroiler breed exhibited the highest $(\mathrm{P}<0.05)$ eviscerated carcass weight, followed by Sasso-R and Koekoek (Table 4). The lowest result is for Horro breed. The highest $(\mathrm{P}<0.05)$ total viscera weight and total edible offal weight were recorded in the Kuroiler and Sasso-R cockerels, followed by Koekoek, whereas the lowest result was recorded for Horro males. The average weight of 
Table 4. Eviscerated carcass and edible offal weight and percent of different male chicken breeds slaughtered at 16 weeks of age.

\begin{tabular}{|c|c|c|c|c|c|c|}
\hline \multirow{2}{*}{ Trait } & \multicolumn{4}{|c|}{ Breed } & \multirow{2}{*}{ SEM } & \multirow{2}{*}{$P$-value } \\
\hline & Ho & Ko & $\mathrm{Ku}$ & Sa-R & & \\
\hline TV (g) & $102.2^{\mathrm{c}}$ & $126.7^{\mathrm{b}}$ & $197.1^{\mathrm{a}}$ & $198.9^{\mathrm{a}}$ & 5.38 & $* * *$ \\
\hline $\mathrm{TV}(\% \mathrm{BW})$ & $7.7^{\mathrm{b}}$ & $7.5^{\mathrm{b}}$ & $7.2^{\mathrm{b}}$ & $8.7^{\mathrm{a}}$ & 0.24 & $* *$ \\
\hline $\operatorname{SEC}(g)$ & $972.3^{\mathrm{d}}$ & $1210.3^{\mathrm{c}}$ & $2003.9^{\mathrm{a}}$ & $1645.9^{\mathrm{b}}$ & 24.9 & $* * *$ \\
\hline SEC (\% BW) & $72.8^{\mathrm{ab}}$ & $71.6^{\mathrm{b}}$ & $73.8^{\mathrm{a}}$ & $72.0^{\mathrm{b}}$ & 0.40 & $* *$ \\
\hline $\mathrm{EC}(\mathrm{g})$ & $890.8^{\mathrm{d}}$ & $1077.0^{\mathrm{c}}$ & $1797.4^{\mathrm{a}}$ & $1463.4^{\mathrm{b}}$ & 22.5 & $* * *$ \\
\hline $\mathrm{EC}(\% \mathrm{BW})$ & $66.7^{\mathrm{a}}$ & $63.7^{\mathrm{b}}$ & $66.2^{\mathrm{a}}$ & $64.0^{\mathrm{b}}$ & 042 & $* * *$ \\
\hline Liver (g) & $31.5^{\mathrm{b}}$ & $37.2^{\mathrm{b}}$ & $52.3^{\mathrm{a}}$ & $58.1^{\mathrm{a}}$ & 2.16 & $* * *$ \\
\hline Liver (\% BW) & $2.4^{\mathrm{a}}$ & $2.2^{\mathrm{b}}$ & $1.9^{\mathrm{b}}$ & $2.5^{\mathrm{a}}$ & 0.09 & $* * *$ \\
\hline Heart (g) & $6.9^{\mathrm{b}}$ & $8.1^{\mathrm{b}}$ & $14.4^{\mathrm{a}}$ & $11.9^{\mathrm{a}}$ & 0.80 & $* * *$ \\
\hline Heart (\% BW) & 0.52 & 0.48 & 0.53 & 0.52 & 0.04 & NS \\
\hline Gizzard (g) & $29.4^{\mathrm{c}}$ & $48.3^{\mathrm{b}}$ & $58.1^{\mathrm{a}}$ & $52.1^{\mathrm{ab}}$ & 2.42 & $* * *$ \\
\hline Gizzard (\% BW) & $2.2^{\mathrm{b}}$ & $2.9^{\mathrm{a}}$ & $2.1^{\mathrm{b}}$ & $2.3^{\mathrm{b}}$ & 0.11 & $* * *$ \\
\hline Skin (g) & $84.5^{\mathrm{b}}$ & $110.8^{\mathrm{b}}$ & $199.5^{\mathrm{a}}$ & $184.0^{\mathrm{a}}$ & 10.06 & $* * *$ \\
\hline Skin (\% BW) & $6.3^{\mathrm{b}}$ & $6.6^{\mathrm{ab}}$ & $7.4^{\mathrm{ab}}$ & $8.0^{\mathrm{a}}$ & 0.41 & * \\
\hline $\mathrm{EO}(\mathrm{g})$ & $152.4^{\mathrm{c}}$ & $204.4^{\mathrm{b}}$ & $324.2^{\mathrm{a}}$ & $306.1^{\mathrm{a}}$ & 11.06 & $* * *$ \\
\hline $\mathrm{EO}(\% \mathrm{BW})$ & $11.4^{\mathrm{b}}$ & $12.1^{\mathrm{ab}}$ & $11.9^{\mathrm{ab}}$ & $13.4^{\mathrm{a}}$ & 0.44 & * \\
\hline $\mathrm{AF}(\mathrm{g})$ & $13.7^{\mathrm{c}}$ & $39.6^{\mathrm{b}}$ & $81.7^{\mathrm{a}}$ & $60.4^{\mathrm{ab}}$ & 6.09 & $* * *$ \\
\hline
\end{tabular}

${ }_{\mathrm{a}, \mathrm{b}, \mathrm{c}, \mathrm{d}}$ Means within a row with different superscript letters are significantly different; ${ }^{* *}=\mathrm{P}<0.001$; ${ }^{* *}=\mathrm{P}<$ $\left.0.01{ }^{\star}=\mathrm{P}<0.05\right) ; \mathrm{AF}=$ Abdominal fat; $\mathrm{EC}^{1}=$ Eviscerated carcass with giblet; $\mathrm{EO}=$ Edible offal $(\mathrm{TG}+$ skin); NS = Non significant; SEM = Standard error of the mean; ${ }^{2} \mathrm{TG}=($ Heart + Liver + Gizzard $) ; \mathrm{TV}=$ Total viscera (Lung + Wind pipe + Kidney + Spleen + Tests + Gall bladder + Digestive tract); Ho = Horro; Ko = Koekoek; $\mathrm{Ku}=$ Kuroiler; Sa-R = Sasso and Rhode Island Red crossbred.

liver, heart and skin were significantly $(\mathrm{P}<0.05)$ higher in Sasso- $\mathrm{R}$ and Kuroiler than Horro and Koekoek. Abdominal fat and gizzard weights were highest $(\mathrm{P}<$ $0.05)$ for Kuroiler and lowest $(\mathrm{P}<0.05)$ in Horro. The average percent eviscerated carcass weight of Horro was similar with Kuroiler, but significantly higher than Koekoek and Sasso-R. The Horro and Sasso-R showed similar $(\mathrm{P}>0.05)$, but higher $(\mathrm{P}<0.05)$ percent liver weight than Kuroiler and Koekoek. The average percent gizzard weight of Koekoek was significantly $(\mathrm{P}<0.05)$ higher than the other treatments. The average percent gizzard weight of Koekoek was significantly higher than the rest treatments. Percent skin and edible offal in the Sasso- $\mathrm{R}$ was similar $(\mathrm{P}>0.05)$ with Kuroiler and Koekoek, but higher $(\mathrm{P}<0.05)$ than Horro. The Horro breed showed significantly $(\mathrm{P}<0.05)$ lower percent abdominal fat weight than all of the other treatments.

\subsection{Weight and Percent Carcass Parts}

The Kuroiler breed recorded the highest thigh weight, drumstick weight, wing weight, neck weight and total carcass weight, while the lowest value was obtained for Horro breed (Table 5). Sasso-R breed recorded significantly higher values 
Table 5. Weight and percent carcass parts of the different male chicken breeds slaughtered at 16 weeks of age.

\begin{tabular}{|c|c|c|c|c|c|c|}
\hline \multirow{2}{*}{ Trait } & \multicolumn{4}{|c|}{ Breed } & \multirow{2}{*}{ SEM } & \multirow{2}{*}{$P$-value } \\
\hline & Ho & Ko & $\mathrm{Ku}$ & Sa-R & & \\
\hline Breast (g) & $276.4^{\mathrm{c}}$ & $292.5^{c}$ & $541.7^{\mathrm{a}}$ & $439.0^{\mathrm{b}}$ & 7.95 & $* * *$ \\
\hline Breast (\% SW) & $20.7^{\mathrm{a}}$ & $17.3^{\mathrm{c}}$ & $19.9^{\mathrm{ab}}$ & $19.2^{\mathrm{b}}$ & 0.31 & $* * *$ \\
\hline Thighs (g) & $155.3^{\mathrm{d}}$ & $186.1^{\mathrm{c}}$ & $303.1^{\mathrm{a}}$ & $238.7^{\mathrm{b}}$ & 6.78 & $* * *$ \\
\hline Thighs (\% SW) & 11.6 & 11.0 & 11.2 & 10.4 & 0.31 & NS \\
\hline Drumstick (g) & $128.5^{\mathrm{d}}$ & $173.2^{\mathrm{c}}$ & $274.8^{\mathrm{a}}$ & $203.5^{\mathrm{b}}$ & 4.34 & $* * *$ \\
\hline Drumstick (\% SW) & $9.6^{\mathrm{a}}$ & $10.2^{\mathrm{a}}$ & $10.1^{\mathrm{a}}$ & $8.9^{\mathrm{b}}$ & 0.17 & $* * *$ \\
\hline $\operatorname{Leg}(\mathrm{g})$ & $283.8^{\mathrm{d}}$ & $359.2^{c}$ & $577.9^{\mathrm{a}}$ & $442.2^{\mathrm{b}}$ & 8.79 & $* * *$ \\
\hline Leg $(\%$ SW) & $21.3^{\mathrm{a}}$ & $21.3^{\mathrm{a}}$ & $21.3^{\mathrm{a}}$ & $19.4^{\mathrm{b}}$ & 0.37 & $* *$ \\
\hline Back (g) & $108.1^{\mathrm{c}}$ & $140.4^{\mathrm{c}}$ & $245.6^{\mathrm{a}}$ & $190.1^{\mathrm{b}}$ & 8.75 & $* * *$ \\
\hline Back (\% SW) & 8.1 & 8.3 & 9.0 & 8.3 & 0.37 & NS \\
\hline Rear (g) & $391.9^{\mathrm{d}}$ & $499.7^{c}$ & $823.5^{\mathrm{a}}$ & $632.3^{\mathrm{b}}$ & 13.5 & $* * *$ \\
\hline Rear (\% SW) & $29.4^{\mathrm{ab}}$ & $29.6^{\mathrm{a}}$ & $30.3^{\mathrm{a}}$ & $27.7^{\mathrm{b}}$ & 0.44 & $* * *$ \\
\hline Wing (g) & $51.8^{\mathrm{d}}$ & $73.0^{c}$ & $95.3^{\mathrm{a}}$ & $82.8^{\mathrm{b}}$ & 2.26 & $* * *$ \\
\hline Wing (\% SW) & $3.9^{\mathrm{b}}$ & $4.3^{\mathrm{a}}$ & $3.5^{\mathrm{b}}$ & $3.6^{\mathrm{b}}$ & 0.10 & $* *$ \\
\hline Neck (g) & $69.3^{\mathrm{d}}$ & $83.2^{\mathrm{c}}$ & $124.3^{\mathrm{a}}$ & $107.3^{\mathrm{b}}$ & 1.62 & $* * *$ \\
\hline Neck (\% SW ) & $5.2^{\mathrm{a}}$ & $4.9^{\mathrm{ab}}$ & $4.6^{\mathrm{c}}$ & $4.7^{\mathrm{bc}}$ & 0.08 & $* *$ \\
\hline $\mathrm{TCP}(\mathrm{g})$ & $791.4^{\mathrm{d}}$ & $948.3^{c}$ & $1580.9^{\mathrm{a}}$ & $1261.3^{\mathrm{b}}$ & 21.62 & $* * *$ \\
\hline TCP (\% SW ) & $59.3^{\mathrm{a}}$ & $56.1^{\mathrm{bc}}$ & $58.2^{\mathrm{ab}}$ & $55.2^{\mathrm{c}}$ & 0.62 & $* *$ \\
\hline
\end{tabular}

${ }_{a, b, c, d}$ Means within a row with different superscript letters are significantly different; ${ }^{* * *}=\mathrm{P}<0.001$; ${ }^{* *}=\mathrm{P}<$ $0.01,{ }^{*}=\mathrm{P}<0.05$; NS $=$ Non significant; SEM $=$ Standard error of the mean; $\operatorname{Leg}^{1}$ (Thigh + Drumstick); Rear $^{2}$ (Thigh + Drusmstic + Back); TCC $=$ Total carcass part $($ Breast + Thigh + Drumstick + Wing + Neck + Back); Ho = Horro; Ko = Koekoek; Ku = Kuroiler; Sa-R = Sasso and Rhode Island Red crossbred.

than Koekoek in these parameters. Breast and back weight were higher $(\mathrm{P}<0.01)$ in Kuroiler, moderate in Sasso-R, and low and similar between Horro and Koekoek breeds. Percent breast weight was significantly higher in Horro than Koekoek and Sasso-R, but the value for Horro was similar with Kuroiler. Lower $(\mathrm{P}<$ 0.05) percent drumstick weight was obtained in the Sasso-R crossbred chicken than the other breeds. The Horro breed has significantly higher percent wing weight than Sasso-R and Kuroiler, but similar $(\mathrm{P}>0.05)$ value with that of Koekoek. The average percent neck weight of Koekoek was significantly higher than Kuroiler and Sasso-R and Horro. The Kuroiler and Horro had similar ( $p>0.05)$, but higher percent total carcass part weight than Sasso-R.

\subsection{Chemical Composition and Sensory Attributes of Meat}

The proximate chemical composition and sensory attributes of two main commercial cuts (breast and thigh) is shown in Table 6. Breasts meat from Horro and Kuroiler breed contained lower percentage of moisture and crude protein (CP) than all of the other breeds, respectively. However, ether extract (EE) and 
Table 6. Chemical composition and sensory attributes of breast and thigh meat of the different chicken breeds slaughtered at 16 weeks of age.

\begin{tabular}{|c|c|c|c|c|c|c|}
\hline \multirow{2}{*}{ Trait } & \multicolumn{4}{|c|}{ Breed } & \multirow{2}{*}{ SEM } & \multirow{2}{*}{$P$-valuc } \\
\hline & Ho & Ko & $\mathrm{Ku}$ & Sa-R & & \\
\hline \multicolumn{7}{|l|}{ Breast muscle } \\
\hline $\mathrm{MO}(\%)$ & $73.0^{\mathrm{b}}$ & $73.9^{\mathrm{a}}$ & $73.8^{\mathrm{a}}$ & $73.9^{\mathrm{a}}$ & 0.13 & * \\
\hline СР (\%) & $24.6^{\mathrm{a}}$ & $22.3^{\mathrm{bc}}$ & $21.5^{\mathrm{c}}$ & $23.4^{\mathrm{ab}}$ & 0.25 & $* *$ \\
\hline $\mathrm{EE}(\%)$ & 3.4 & 3.6 & 3.7 & 3.4 & 0.07 & NS \\
\hline $\mathrm{TA}(\%)$ & 1.5 & 1.5 & 1.3 & 1.3 & 0.07 & NS \\
\hline Tenderness & 4.88 & 5.50 & 5.38 & 5.63 & 0.53 & NS \\
\hline Juiciness & 4.00 & 5.63 & 4.75 & 4.75 & 0.50 & NS \\
\hline Flavor & 5.88 & 6.13 & 5.50 & 6.00 & 0.40 & NS \\
\hline General acceptability & 5.50 & 5.75 & 5.63 & 6.13 & 0.36 & NS \\
\hline \multicolumn{7}{|l|}{ Thigh muscle } \\
\hline $\mathrm{MO}(\%)$ & $71.9^{\mathrm{b}}$ & $72.8^{\mathrm{a}}$ & $72.7^{\mathrm{a}}$ & $72.8^{\mathrm{a}}$ & 0.13 & * \\
\hline $\mathrm{CP}(\%)$ & $20.3^{\mathrm{a}}$ & $18.4^{\mathrm{ab}}$ & $17.4^{\mathrm{b}}$ & $18.1^{\mathrm{ab}}$ & 0.43 & * \\
\hline $\mathrm{EE}(\%)$ & $5.6^{\mathrm{c}}$ & $6.9^{\mathrm{b}}$ & $7.0^{\mathrm{b}}$ & $8.9^{\mathrm{a}}$ & 0.22 & $* *$ \\
\hline TA (\%) & $1.5^{\mathrm{a}}$ & $1.3^{\mathrm{b}}$ & $1.3^{\mathrm{b}}$ & $1.0^{c}$ & 0.03 & $* * *$ \\
\hline Tenderness & 4.00 & 3.67 & 5.11 & 5.33 & 0.52 & NS \\
\hline Juiciness & 4.78 & 5.33 & 5.11 & 6.11 & 0.43 & NS \\
\hline Flavor & 5.00 & 5.67 & 5.56 & 6.00 & 0.51 & NS \\
\hline General acceptability & 5.33 & 4.89 & 5.78 & 6.11 & 0.48 & NS \\
\hline
\end{tabular}

${ }^{\mathrm{a}, \mathrm{b}, \mathrm{c}, \mathrm{Means}}$ within a row with different superscript letters are significantly different; ${ }^{* * *}=\mathrm{P}<0.001 ;{ }^{*}=\mathrm{P}<$ $0.001 ; \mathrm{NS}=$ Non Significant; $\mathrm{SEM}=$ Standard error of the mean; $\mathrm{MO}=$ Moisture; $\mathrm{CP}=$ Crude protein; $\mathrm{EE}=$ Ether extract; $\mathrm{TA}=$ Total ash; Ho $=$ Horro; Ko = Koekoek; Ku = Kuroiler; Sa-R = Sasso and Rhode Island Red crossbred.

total ash (TA) content of breast meat were similar among breeds. Thigh meat from Koekoek, Kuroiler and Sasso-R breed contained higher moisture and EE than that of Horro breeds. The Horro breed also had higher CP content of thigh meat than Kuroiler. However, CP content of thigh meat in the Koekoek, Kuroiler and Sasso-R breeds were similar. Total ash content of thigh meat is highest in Horro, intermediate in Koekoek and Kuroiler, lowest in Sasso-R. The overall comparison of nutrient content between breast and thigh meat revealed that all of the breeds contained higher moisture and $\mathrm{CP}$, but lower $\mathrm{EE}$ in the breast than thigh meat. There was higher percentage of TA in breast meat than thigh in Koekoek, whereas it is not different among Horro, Kuroiler and Sasso- $\mathrm{R}$ in both the breast and thigh meat. The flavor, tenderness, juiciness and general acceptability of breast and thigh meat were not affected by breed of chicken.

\subsection{Economic Analysis}

Feed cost per bird, total variable cost (TVC), total return (TR) and net return (NR) was higher in Kuroiler breed followed by Sasso-R and Horro (Table 7). 
Table 7. Economics of rearing cockerels of egg-type chicken breeds for meat production from 8 - 16 weeks of age under intensive management.

\begin{tabular}{ccccccc}
\hline \multirow{2}{*}{ Cost and revenue } & \multicolumn{7}{c}{ Breed } & \multirow{2}{*}{ SEM } & $P$-value \\
\cline { 2 - 5 } & Ho & Ko & Ku & Sa-R & & \\
\hline Feed consumption (kg/Bird) & $4.4^{\mathrm{d}}$ & $5.4^{\mathrm{c}}$ & $7.1^{\mathrm{a}}$ & $5.9^{\mathrm{b}}$ & 0.09 & $* * *$ \\
Feed cost (Birr/kg) & 12.5 & 12.5 & 12.5 & 12.5 & 0.00 & NS \\
Feed cost (Birr/bird) & $55.1^{\mathrm{d}}$ & $68.1^{\mathrm{c}}$ & $89.2^{\mathrm{a}}$ & $73.8^{\mathrm{b}}$ & 1.18 & $* * *$ \\
Vaccine cost (Birr /bird) & 1.68 & 1.68 & 1.68 & 1.68 & 0.00 & NS \\
Labor cost (Birr /bird) & 8.68 & 8.68 & 8.68 & 8.68 & 0.00 & NS \\
Total variable cost (Birr) & $65.4^{\mathrm{d}}$ & $78.7^{\mathrm{c}}$ & $84.1^{\mathrm{a}}$ & $99.5^{\mathrm{b}}$ & 1.18 & $* * *$ \\
Meat yield (kg)/Bird & 0.97 & 1.2 & 2.0 & 1.6 & 0.13 & $* * *$ \\
Price of 1 kg meat (Birr) & 150.0 & 150.0 & 150.0 & 150.0 & 0.00 & NS \\
Live cockerels sale (Birr/bird) & 150.0 & 150.0 & 150.0 & 150.0 & 0.00 & NS \\
TR (Birr) & $146.0^{\mathrm{d}}$ & $181.0^{\mathrm{c}}$ & $300.5^{\mathrm{a}}$ & $247.0^{\mathrm{b}}$ & 2.09 & $* * *$ \\
NR (Birr) & $80.6^{\mathrm{d}}$ & $102.3^{\mathrm{c}}$ & $201.0^{\mathrm{a}}$ & $162.9^{\mathrm{b}}$ & 2.15 & $* * *$ \\
\hline
\end{tabular}

${ }_{\mathrm{a}, \mathrm{b}, \mathrm{c}, \mathrm{d}}$ Means within a row with different superscript letters are significantly different; ${ }^{* *}=\mathrm{P}<0.001$; NS $=$ Non significant; SEM = Standard error of the mean; Ho = Horro; Ko = Koekoek; Ku = Kuroiler; Sa-R = Sasso and Rhode Island Red crossbred; Birr = Ethiopian currency; TR = Total return; NR = Net return.

However, vaccine cost and labor cost per birds was similar $(\mathrm{p}>0.05)$ among the breeds.

\section{Discussion}

\subsection{Body Weight, Body Weight Change and Average Daily Gain}

The result of the present study shows the existence of large variation in body weight among the different genetic groups where the Kuroiler breed exhibited better result than Sasso-R, Koekoek and Horro breeds. The result is consistent with body weight reported for dual-purpose chickens reared for meat production [17] [7] [18]. The higher body weight of Kuroiler than others is attributed to the genetic potential of the breed as a commercial strain. The breed is developed by selection and strain crossing by Kegg farms, India [6] and reference [19] noted that body weight of male chickens at 11 week of age has increased from $924.7 \mathrm{~g}$ to $1443.6 \mathrm{~g}$ through selection.

The average body weight of Kuroiler, Sasso-R and Koekoek chickens was lower than the report for Vanaraja chicken at 8,12 and 16 weeks of age [20]. The genetic potential and the use of meat-type strains to develop the Vanaraja chicken might be responsible for the higher body weight of the breed than the result in the current study. However, Kuroiler and Sasso-R achieved higher BW than reported by [17] for three male dual -purpose chickens at 8, 12, 14 and 16 weeks of age. The combined effect of breed and the feeding management could be the reasons for the variation in body weight among different strains of birds. The mean body weight of Koekoek at 14 and 16 weeks of age was higher than 
that the reported by [21], but lower than obtained by [18] for the same breed managed under similar conditions. This suggests that apart from the inherited breed difference, environmental factors such as feeding and management conditions are critical factors influencing body weight of chickens [7] [22]. The average body weight of local Horro was lower than recorded for CARI Nirbheek male chickens at 10,12 and 16 weeks of age [23]. However, the breed recorded higher result than the report for indigenous breeds from Uganda at 10, 12, 14 and 16 weeks of age [22]. This could be due to the mass selective breeding that has been undertaken to improve the performance of the breed for generations [5].

The higher average daily gain (ADG) of Kuroiler in this study is in agreement with earlier studies [17] [18]), which could be ascribed to the genetic selection to improve growth rate of the breed/strain. The average daily gain of Kuroiler, Sasso-R and Koekoek was lower than that reported by [7] for Ross PM3, Sasso 51 and Lohmann Dual, but higher than for Belgian Malines, Schweizerhuhn and Lohmann Brown breeds. Male Kuroiler chickens achieved comparable weight gains $(28.9 \mathrm{~g} /$ day) with that of ISA 657 slow-growing broiler (26 to $34 \mathrm{~g} /$ day) reared for meat production from hatching to 84 days of age [14]. The average daily gain reported by [17] for male chickens from Rhode Island Red, Black Australorp and Barred Plymouth Rock breeds were lower than the result for Kuroiler, Koekoek and Sasso-R, but slightly higher than for Horro. The result recorded by Horro, Koekoek and Sasso-R were higher than that reported by [24] for the breeds managed under semi-scavenging condition suggesting that the semi-scavenging condition might have not allowed the full genetic expression of the breeds. However, the result recorded by Koekoek and Horro were lower than that reported by Packard [25].

Body weight and average daily weight gain are considered as a good measure of growth in meat type birds. Poultry production with dual-purpose lines has become common in low-input family production system in Ethiopia. These types of chicken appear to be ideal for such production system, where the females are used for egg production and the males for meat production. The final body weight of Kuroiler, Sasso-R and Koekoek are comparable to that of 8 weeks old broilers despite the longer growing period required to attain similar gain. Thus, raising the male chickens for meat production will increase total production and provide extra cash income to producers.

\subsection{Feed Consumption, Feed Conversion Ratio and Mortality}

The existence of significant differences in feed intake among breeds of chickens reared for meat production has been reported in several studies [11] [18]. Higher result for Kuroiler goes along with higher growth performance exhibited by the breed. The Kuroiler breed gained $100.5 \%, 53.3 \%$ and $34.5 \%$ more weight than Horro, Koekoek and Sasso-R, respectively. It is well known that the variation in growth rate will affect the mechanisms of feed intake and nutrient utilization in 
meat type birds. Likewise, [26] reported a higher degree of relationship between growth performance and the amount of feed consumed by Broiler strains. The Kuroiler breed consumed less feed per day than reported by [27] for Giriraja male chicken reared up to 12 weeks of age, but more feed than that reported by [28] for three broiler strains. The amount of feed consumed by Koekoek, Sasso-R and Horro was lower than the average daily feed intake reported by [17] for Cornish cross male, but higher than dual-purpose male chickens.

Feed conversion ratio (FCR) is the most common method used to evaluate efficiency in poultry production. The best FCR in the current study was observed in the Kuroiler male. The breed grew faster ( $28.9 \mathrm{~g} /$ day) with a final weight that was 1.9 times heavier than the indigenous Horro. This is in agreement with [7] who reported that Ross PM3 commercial broilers grew faster, consumed more feed and converted feed into gain more efficiently compared with dual-purpose chickens and slow-growing broilers. Greater efficiency in the Kuroiler male could be attributed to the continuous selection carried out to develop the breed. Many genetic studies have shown that feed conversion ratio in poultry could be improved through selection. Mass selection in traditional Belgian chicken breed over four generations has improved FCR from 5.97 to 3.64 [19]. Thus, feed conversion ratio remains an important criterion in selection programs, because feed costs represent the greatest expense for meat production. Therefore, the reduction of FCR through selection has a major impact on the profitability of meat production.

The FCR value of the Kuroiler breed in the current study was higher than that reported by [25] who found FCR ranging from 3.58 - 3.88 for Australorp, New-Hampshire, Koekoek and Naked-Neck dual-purpose male chickens. However, the breed achieved lower FCR than that reported by [22] and [28] for male Kuroiler chickens. The reason for such discrepancies might be due to the differences in the compositions of diets used and/or management procedures followed in the three studies. The average FCR of Koekoek breed was higher than the finding of [18] for male chickens of the same breed reared for meat production up to 16 weeks of age, but lowers than that reported by [29] for Koekoek cockerels fed control diet. A study by [26] observed a higher degree of relationship between body weight and daily gain, and FCR in broiler strains. Similar FCR between Sasso-R and Koekoek, despite the higher feed consumption in the former breed, suggests that the two breeds used the feed with the same degree of efficiency. The mean FCR of Horro male chickens was much lower than that reported for indigenous chickens from Nigeria managed under similar condition [28].

Mortality always represents a major economic loss in poultry production enterprise. The lowest mortality was observed in Sasso- $\mathrm{R}$ than Kuroiler and Koekoek. The result is in agreement with previous studies that found difference in mortality among different breeds/strains of chicken managed under similar condition [28]. The mean percentage mortality of birds was lower than the $15 \%$ standard set for the industry during the rearing period ( $9-20$ weeks) in a tropi- 
cal climate [30].

\subsection{Slaughter Weight and Dressed Carcass}

Several authors have reported the existence of breed/genotype difference in slaughter weight of chickens. The higher slaughter weight of Kuroiler males than birds from other breeds may be attributed to the fast growth rate and weight gain of the breed. Similarly, [26] reported higher slaughter weight in birds having higher average daily gain. The average slaughter weight of Kuroiler, Sasso- $\mathrm{R}$ and Koekoek breed was lower than the value reported by [18] for Novo color egg type male chickens, but higher than the value for Dominant Sussex. Likewise, [26] reported lower slaughter for Belgian Malines and Schweizerhuhn male chickens than the result in the current study. The Horro breed exhibited higher body weight at slaughter than the findings of [31] for dominant black and Yaffa brown cockerels.

Body weight at slaughter is an important economic trait that determines market value of meat type birds. The majority of chicken meat for human consumption in developing countries is largely derived from cockerels of egg-producing breeds and spent hens, mainly indigenous chickens. This is because; meat production from broilers is not well developed. Despite the slow growth rate and the extended rearing period required to reach slaughter weight, cockerels of dual-purpose chicken attain comparable body weight with that of broilers (1487.8 g - 1750.4 g) at 42 days of age [32]. Dressed weight is another important economic trait in meat type birds next to body weight at slaughter. Greater dressed carcass weight recorded by Kuroiler breed was expected because of the high body weight of the breed at slaughter. The higher result of the Kuroiler breed in the current study agree with earlier study by [33] who observe higher value in chickens with heavier body weight at slaughter.

The average dressed weight recorded in the present study was lower than the report by [34] in four chicken genotypes, but higher than the value for Dominant Sussex male chicken [18]. Lower percent dressed carcass of Koekoek than Kuroiler and Sasso- $\mathrm{R}$ in the current study was in line with [7] who noted higher result for Lohmann Dual, Belgian Malines, Schweizerhuhn compared to Lohmann Brown male chickens. The Kuroiler and Sasso-R, and Koekoek and Horro recorded similar dressed carcass percentage despite their difference in body weight at slaughter. This could be due to relatively higher dressing loss of Sasso-R (19.3) than Kuroiler and Koekoek (20.9\%) than Horro breeds. The result recorded by the Kuroiler, Sasso-R and Horro were lower than the value obtained in four chicken genotypes [34]. However, all the breeds in the current study achieved higher result than that reported for slower-growing broilers and dual-purpose chicken [7].

\subsection{Eviscerated Carcass and Edible Offal}

Higher semi-eviscerated and eviscerated carcass weight recorded by Kuroiler 
breed was in agreement with [34] who obtained higher result in crosses compared with pure lines. The higher value for Kuroiler chickens is due to the higher body weight of the breed at slaughter. Positive phenotypic correlation was reported by [35] between live weight and eviscerated weight $(r=0.98)$ in Arbor Acre broiler chicken. The average semi-eviscerated and eviscerated weight recorded was lower than the result reported for two crossbred chicken genotypes [34]. However, Kuroiler, Sasso-R and Koekoek recorded higher eviscerated carcass weight than Dahlem Red chicken [36]. The eviscerated carcass weight exhibited by Horro was higher than the result reported for dominant black and Yaffa brown cockerels [31]. The observation by [34] reported percent semi eviscerated weight to range $81.9-82.6$, which is higher than the value obtained in the present study. The average percentage eviscerated weight of Kuroiler and Horro is lower the $69.1 \%$ reported for male Bresse-Gauloise by [37], but comparable to the $66.6 \%$ reported for male and female Bresse-Gauloise by [38]. The higher eviscerated weight observed in meat type chicken determines the potential of the genotype for meat production. Thus, average percent eviscerated carcass obtained in the present study could be regarded as satisfactory for meat production.

Edible offal which includes gizzard, heart, liver and skin are important component of chicken meat. The higher liver, heart, gizzard, skin and total edible offal weight exhibited by the Kuroiler than that of Horro and Koekoek was in line with the finding of earlier reports on egg type dual purpose male chicken and synthetic breeds [17] [18] [39]. The genetic correlation between body weight and the weight of internal organs is responsible for the higher liver, heart, gizzard and skin weight recorded by the Kuroiler breed. Likewise, [11] reported higher liver, heart and gizzard weight in chickens with heavy body weight. Similar liver, heart, skin and total edible offal weight in the Kuroiler and Sasso-R, despite the higher body weight in the former breed is difficult to explain. The average heart, liver and gizzard weight of Kuroiler in the current study was lower than the result reported by [11] for Color synthetic male line chickens with a slaughter weight of $2271.3 \mathrm{~g}$. However, heart weight and gizzard weight were comparable with the result reported by [17] for Red Ranger and Barred Plymouth Rock chickens, respectively. This implies that Kuroiler exhibited comparable yield of edible offal with dual-purpose chickens. Low liver and heart, but high gizzard weights were exhibited by Horro breed when compared with Naked Neck male chicken with comparable body weight [40]. Edible offal is included in the edible portion of chicken meat by most Ethiopian consumers. Thus, higher weight in the carcass from Sasso- $\mathrm{R}$ and Kuroiler breed will increase the total meat harvested per bird.

The proportion of liver weight was higher in the carcass from Horro and Sasso-R breed, while the Koekoek breed exhibited higher percentage gizzard weight. Reference [18] reported higher percent liver weight in Dominant Sussex than Dominant Red Barred, Novogen Brown and Novogen Color, while higher per- 
centage gizzard weight for Dominant Sussex than Novogen Color breeds. Similarly, reference [41] obtained higher percentage liver and gizzard weight in pure Bresse-Gauloise than Bresse-Gauloise $\times$ New Hampshire crosses. Selection for growth rate will affect the degree of maturity at slaughter and this in turn will affect the relative weight of different organs at any given age [42]. Reference [43] reported variation in liver, heart and gizzard weight percentage between slow growing unselected Wuding and intensively selected fast growing Daweishan chickens.

The mean liver weight percentage of Sasso-R and Horro were higher, while that of Koekoek and Kuroiler were within the range reported for male chickens of commercial layers and experimental crosses [18]. However, the result reported by [41] for pure Bresse-Gauloise male chickens is within the range for Sasso-R and Horro breeds. The greater proportion of liver in Sasso-R, though not significant, suggests a more important function of the liver during growth compared to the other organs for the breed. The proportion of gizzard weight reported by [41] for pure Bresse-Gauloise male chickens slaughtered between 18-19 weeks of age was comparable with Koekoek, but higher than the other three breed in the current study. However, the proportion of gizzard weight in the current study is within the range reported by [44] in four genetic groups. Percent heart weight of the four genetic groups in the current study were lower than [41], but within the range reported by [44] in four genetic groups. The higher abdominal fat weight and percentage in the exotic breeds than indigenous Horro is attributed to correlation of the trait with selection for rapid growth and high live weight. Abdominal fat weight of Kuroiler breed was lower than the result reported by [34] in four chicken genotypes with comparable body weight. Abdominal fat weight percent recorded is within the acceptable $3 \%$ range for broiler chickens.

\subsection{Weight and Percent Carcass Parts}

The weight of breast, thigh, drumstick, wing, neck and back followed a similar pattern as body weight at slaughter. The result is consistent with earlier reports for egg type male chickens [39] [36]. The explanation for the higher value in Kuroiler is the genetic association between slaughter weight and weight of individual carcass parts. Slaughter weight has significant $(\mathrm{P}<0.01)$ positive phenotypic correlation with breast weight $(r=0.89)$, thigh weight $(r=0.95)$, back weight $(r=0.96)$ and drumstick weight $(r=0.92)$ in broiler chicken [35]. In addition, reference [45] reported higher breast, wing, neck and back weight in chickens with heavier slaughter weight.

Breast, thigh and drumstick are the most valuable carcass part in broilers and dual-purpose chickens kept for meat production. The average breast and thigh weight for Kuroiler breed is lower than that reported by [9] for Cobb broiler strain with slightly higher slaughter weight. However, the breed recorded higher breast and leg weight than four chicken genotypes with comparable slaughter 
weight [34] and higher breast weight than synthetic broiler lines [11] and Marshall Broiler chickens [9]. These implies that Kuroiler as a dual purpose breed exhibited comparable breast meat with commercial broiler chickens and synthetic broiler lines. Breast, thigh and drumstick weight exhibited by Sasso-R and Koekoek was higher than the result for Dahlem Red chicken [36]. The Horro breed recorded higher breast, neck, drumstick and thigh weight, but lower wing weight than the result for Naked Neck male chicken with comparable body weight [40]. The breed also recorded comparable breast weight with those of other studies involving indigenous chickens from Uganda [22].

The difference in the proportion of breast, drumstick, wing and neck among breeds in the current study is in line with earlier studies [7] [18] [25]. The relative weight of carcass part can be affected by a number of factors including genetic make-up. The breast weight percentage was lowest for the Koekoek males leading to a higher proportion of less valuable parts (wings and neck). The proportion of breast in the carcasses from Horro and Kuroiler breeds was lower than that reported by [18] for Novo Brown male chickens and by [45] for Shrinidhi and Vanaraja chicken, but higher than the results obtained in four chicken genotypes with comparable slaughter body weight [34]. The Koekoek and Horro recorded the highest wing and neck weight percentage, respectively indicating a higher proportion of less valuable carcass in the two breeds. However, the average wing and neck weight in the carcass of Koekoek and Horro breed $(4.3 \%$ and $5.2 \%$, respectively) is within the range reported by [18] for egg type male chickens. Generally, the slow growth rate and extended rearing period required to reach slaughter weight did not affect the proportion of valuable parts in the carcass of male chickens.

\subsection{Chemical Composition and Sensory Attribute of Meat}

The difference found among breed on moisture and crude protein $(\mathrm{CP})$ content of breast meat is in line with the observation by [46] who reported low moisture and high CP in Polverara genetic group compared with two commercial broiler chickens. The slow growth rate of the breed might be responsible for the low moisture and high CP content of the meat. Reference [7] reported high moisture and low CP content $(\mathrm{g} / \mathrm{kg})$ in fast-growing commercial broilers (Ross PM3) than traditional dual-purpose breeds (Belgian Malines and Schweizerhuhn). The variation in biochemical processes involved in metabolism between fast and slow growing birds may affect the composition of meat. The values of moisture and $\mathrm{CP}$ content of breast meat was within the range reported by [46] for egg-type male growing chickens, white-mini broilers and commercial broilers. However, reference [47] reported higher moisture content of 74.0 for thigh meat of male birds from four chicken genotypes. The high ether extract (EE) content of thigh muscle from Sasso-R breed is consistent with that reported by [7] who noted higher EE content for broilers (Ross PM3 and Sasso 51) than traditional dual-purpose breeds. However the result is lower than the EE content of thigh meat reported for three 
commercial chickens [48]. The low EE and high CP content of breast and thigh meat from indigenous Horro is an important observation with regard to meat quality.

Sensory evaluation is a useful tool for quality assessment of the various foods, including meat. The absence of significant difference on sensory attribute (flavor, tenderness, juiciness and general acceptability) of breast and thigh meat was in accordance with earlier investigations by [10]. Reference [49] reported similar juiciness, flavor and general acceptability of cockerel meat from three chicken breeds. The similarity in sensory score among the different genotypes despite the variation in nutrient content could be due to the capacity of the panelists to discriminate meat from different breeds. Although not significant, breast and thigh meat from the Sasso- $\mathrm{R}$ breed received higher score for tenderness, flavor and general acceptability which could be an attribute of higher EE content of the meat.

\subsection{Economic Analysis}

The Kuroiler male had higher total return (TR) and net return (NR), followed by Sasso-R, then Koekoek and the least in Horro. The reason for the higher result in the Kuroiler could be the higher growth rate and body weight at slaughter achieved by the breed. Meat bird with higher body weight at slaughter will result in higher meat yield. These results were supported by [41] who reported higher profit in birds with fast growth rate. In the present study the cost of housing, equipment and birds were not considered in determining net return. When the cost of housing and equipment, medication and birds are fully determined in dual-purpose chicken the estimated net return per birds will decline by 11.4, 10.0 and $2.7 \%$, respectively [50].

\section{Conclusion}

Breed has significant effect on most of the parameters studied. The Kuroiler breed was superior in body weight and body weight change, average daily gain, feed consumption and feed conversion ratio and meat yield as compared to the other breeds of cockerels. The Kuroiler breed had higher weight of most carcass components and returned greater profit. Sasso- $\mathrm{R}$ has also greater performance than Koekoek and Horro. Therefore, the greater growth performance and carcass traits of Kuroiler and Sasso- $\mathrm{R}$ crossbred chickens could be harnessed for meat production in Ethiopia where intensive broiler production is not well developed. The average BW of the three exotic breed at 16 weeks of age was higher than the marketable size of $1500 \mathrm{~g}$ for dual purpose chickens warranting the need to sell the cockerels at earlier age.

\section{Limitations of the Study}

Since sex differentiation at hatching was not possible, the experimental animals used in this study were 8 weeks old male. Therefore, performance of birds rec- 
orded from 8 - 16 weeks of age was used in the evaluation of the different genotypes. Due to this the performance of male chickens for meat production from hatching to slaughter could not be assessed.

\section{Acknowledgements}

The authors would like to express their deepest gratitude to African Chicken Genetic Gain (ACGG) project for providing the research budget. The authors are also thankful to Haramaya University for providing facilities to undertake the research.

\section{Conflicts of Interest}

The authors declare no conflicts of interest regarding the publication of this paper.

\section{References}

[1] Food and Agriculture Organization (FAO) (2018) FAOSTAT Statistical Database.

[2] Food and Agriculture Organization (FAO) (2014) FAOSTAT Statistical Database.

[3] Central Statistical Agency (CSA) (2018) Federal Democratic Republic of Ethiopia, Central Statistical Agency, Agricultural Sample Survey 2017/18, Livestock and Livestock Characteristics. Statistical Bulletin 587, Addis Ababa.

[4] Hundie, D.S. (2020) Evaluation of Productive and Reproductive Performances of Different Strains of Chickens under Varied Management Systems in Western Ethiopia. Ph.D. Dissertation, Addis Ababa University, Addis Ababa.

[5] Esatu, W. (2015) Genetic Improvement in the Indigenous Chicken of Ethiopia. Ph.D. Dissertation, Wageningen Institute of Animal Sciences, Wageningen.

[6] Sharma, J., Xie, J., Boggess, M., Galukande, E., Semambo, D. and Sharma, S. (2015) Higher Weight Gain By Kuroiler Chickens Than Indigenous Chickens Raised Under Scavenging Conditions By Rural Households In Uganda. Livestock Research for Rural Development, 27, Article No. 178. http://www.lrrd.org/lrrd27/9/shar27178.html

[7] Muller, S.K. (2018) Meat and Egg Production with Dual-Purpose Poultry: Biological Background, Feed Requirements and Efficiency, Meat and Egg Quality. Ph.D. Dissertation, ETH Zurich Research College, Zurich.

[8] Food and Agriculture Organization (FAO) (2019) Poultry Sector Ethiopia. Animal Production and Health Livestock Country Reviews. No. 11, FAO, Rome.

[9] Ojedapo, L.O., Amao, S.R. and Ogunsola, O.O. (2015) Variation of Meat-Type Chickens in Relation to Genotypes and Age of Slaughter on Carcass Indices. Journal of New Sciences, Agriculture and Biotechnology, 14, 473-478.

[10] Rajkumar, U., Muthukumar, M., Haunshi, S., Niranjan, M., Raju, M.V., Rao, S.V. and Chatterjee, R.N. (2016) Comparative Evaluation of Carcass Traits and Meat Quality in Native Aseel Chickens and Commercial Broilers. British Poultry Science, 57, 339-347. https://doi.org/10.1080/00071668.2016.1162282

[11] Ekka, R. (2015) Evaluation of performance of CSML $\times$ Hansli Crosses from 0 to 8 Weeks of Age under Intensive System of Management. M.Sc. Thesis, Orissa University of Agriculture and Technology, Bhubaneswar.

[12] Grobbelaar, J.A.N., Sutherland, B. and Molalakgotla, N.M. (2010) Egg Production 
Potentials of Certain Indigenous Chicken Breeds from South Africa. Animal Genetic Resources, 46, 25-32. https://doi.org/10.1017/S2078633610000664

[13] Association of Official Analytical Chemists (AOAC) (2000) Official Methods of Analysis of AOAC. 17th Edition, AOAC, Gaithersburg, MD.

[14] Upton, M. (1979) Farm Management in Africa, the Principal of Production and Planning. Oxford University Press, Oxford.

[15] Statistical Analysis Systems (SAS) (2013) User's Guide. SAS Institute Inc., Cary.

[16] National Research Council (NRC) (1994) Nutrient Requirements of Poultry. 9th Edition, National Academy Press, Washington DC.

[17] Fisher, T.M. (2016) Specialty Poultry Production: Impact of Genotype, Feed Strategies, Alternative Feedstuffs, and Dietary Enzymes on the Growth Performance and Carcass Characteristics of Heritage Breed Chickens. Ph.D. Dissertation, University of Kentucky, Lexington.

[18] Dawud, I. (2019) Comparative Study of Production and Reproductive Performance of Parent Stock and Commercial Layer Chickens under Different Management Conditions in Ethiopia. Ph.D. Dissertations, Addis Ababa University, Addis Ababa.

[19] Lariviere, J.M., Michaux, C., Verleyen, V. and Leroy, P. (2009) Heritability Estimate and Response to Selection for Body Weight in the Ardennaise Chicken Breed. International Journal of Poultry Science, 8, 952-956.

https://doi.org/10.3923/ijps.2009.952.956

[20] Kundu, A., De, A.K., Kundu, M.S., Sunder, J., Jeyakumr, S. and Sujatha, T. (2015) Production Performance of Indigenous Nicobari Fowls, Vanaraja and Their Various F1 Crosses under Hot Humid Climate of Andaman and Nicobar Islands, India. Indian Journal of Animal Sciences, 85, 172-177.

[21] Bekele, D. and Tadasse, T. (2018) Introduction and Evaluation of Dual Purpose Chicken (Potchefstroom Koekoek) Breed at Bako Agricultural Research Center (BARC). Journal of Biology, Agriculture and Health Care, 8, 74-78.

[22] Aline, K. (2015) Management Systems and Location Effects on Growth and Carcass Traits of Kuroiler and Local Chickens. M.Sc. Thesis, Makerere University, Kampala.

[23] Khadda, B.S., Lata, K., Kumar, R., Jadav, J.K., Singh, B. and Palod, J. (2017) Production Performance and Economics of CARI Nirbheek Chicken for Backyard Farming under Semi-Arid Ecosystem in Central Gujarat, India. Indian Journal of Animal Research, 51, 382-386. https://doi.org/10.18805/ijar.8421

[24] Feked, G. (2018) Characterization of Chicken Production System and on-Farm Evaluation Of Introduced Strains And Improved Horro Chicken in Bako Tibe and Dano Districts of Oromia Region, Ethiopia. M.Sc. Thesis, Haramaya University, Haramaya.

[25] Packard, R. (2014) Comparison of Production Parameters and Meat Quality Characteristics of South African Indigenous Chickens. M.Sc. Thesis, Stellenbosch University, Stellenbosch.

[26] Amao, S.R., Ojedapo, L.O. and Sosina, O.A. (2011) Evaluation of Growth Performance Traits in Three Strains of Broiler Chickens Reared in Derived Savanna Environment of Nigeria. World Journal of Young Researchers, 1, 28-31.

[27] Neupane, D., Karki, M. and Shrestha, S.B. (2014) Intensive Management of New Hampshire and Giriraja Chickens for Generating Premium Cash Income. Nepal Journal of Science and Technology, 15, 23-28.

https://doi.org/10.3126/njst.v15i2.12109

[28] Bamidele, O., Sonaiya, E.B., Adebambo, O.A. and Dessie, T. (2019) On-Station Per- 
formance Evaluation of Improved Tropically Adapted Chicken Breeds for Smallholder Poultry Production Systems in Nigeria. Tropical Animal Health and Production, 52, 1541-1548. https://doi.org/10.1007/s11250-019-02158-9

[29] Manyeula, F. (2018) Physiological Responses and Meat Quality of Potchefstroom Koekoek Cockerels Offered Canola Meal as an Alternative to Soybean Meal. Ph.D. Dissertation, North-West University.

[30] Food and Agriculture Organization (FAO) (2003) Egg Production: A Guide for the Production and Sale of Eggs. Bulletin No. 150, FAO, Rome.

[31] Egbeyale, L.T., Abiola1, S.S., Sogunle, O.M. and Ozoje, M.O. (2011) Effect of Egg Size and Strain on Growth Performance of Cockerel. Agriculture and Biology Journal of North America, 2, 1445-1453.

[32] Nigussu F. (2018) Replacement Value of Ensete ventricosum Corm and Kocho for Maize in Broiler and Layers Ration. Ph.D. Dissertation, Haramaya University, Haramaya.

[33] Rezaei, M., Yngvesson, J., Gunnarsson, S., Jönsson, L. and Wallenbeck, A. (2018) Feed Efficiency, Growth Performance, and Carcass Characteristics of a Fast- and a Slower-Growing Broiler Hybrid Fed Low- or High-Protein Organic Diets. Organic Agriculture, 8, 121-128. https://doi.org/10.1007/s13165-017-0178-6

[34] Yin, H.D., Gilbert, E.R., Chen, S.Y., Wang, Y., Zhang, Z.C., Zhao, X.L., Zhang, Y. and Zhu, Q. (2013) Effect of Hybridization on Carcass Traits and Meat Quality of Erlang Mountainous Chickens. Asian-Australasian Journal of Animal Sciences, 26, 1504-1510. https://doi.org/10.5713/ajas.2013.13097

[35] Olawumi, S.O. (2013) Phenotypic Correlations between Live Body Weight and Carcass Traits in Arbor Aacre Breed of Broiler Chicken. International Journal of Science and Nature, 4, 145-149.

[36] Kalita, N, Pathak, N. and Ahmed, M. (2017) Comparative Evaluation of Various Traits of PB-2 X Indigenous and Dahlem Red Chicken under Intensive System of Rearing. Journal of Entomology and Zoology Studies, 5, 156-159.

[37] Muth, P., Ghaziani, S., Klaiber, I. and Valle Zárate, A. (2018) Are Carcass and Meat Quality of Male Dual-Purpose Chickens Competitive Compared to Slow-Growing Broilers Reared under a Welfare-Enhanced Organic System? Organic Agriculture, 8, 57-68. https://doi.org/10.1007/s13165-016-0173-3

[38] Pinent, T., Reis, L., Dorn, J. and Konig, S. (2015) Comparison of Fattening, Carcass and Survival Traits of Endangered Chicken Breeds Using a Controlled Experimental Design. Zuchtungskunde, 87, 423-436.

[39] Kgwatalala, P.M., Bolowe, A.M., Thutwa, K. and Nsoso, S.J. (2013) Carcass Traits of the Naked-Neck, Dwarf and Normal Strains of Indigenous Tswana Chickens under an Intensive Management System. Agriculture and Biology Journal of North America, 4, 413-418.

[40] Ahmad, S. (2019) Performance of Rhode Island Red, Black Australorp and Naked Neck Crossbred under Free Range, Semi Intensive and Intensive Housing Systems. Ph.D. Dissertation, University of Veterinary and Animal Sciences, Lahore.

[41] Lambertz, C., Wuthijaree, K. and Gauly, M. (2018) Performance, Behavior, and Health of Male Broilers and Laying Hens of 2 Dual-Purpose Chicken Genotypes. Poultry Science, 97, 3564-3576. https://doi.org/10.3382/ps/pey223

[42] Tallentire, C.W., Leinonen, L. and Kyriazakis, L. (2016) Breeding for Efficiency in the Broiler Chicken. A Review. Agronomy for Sustainable Development, 36, Article No. 66. https://link.springer.com/article/10.1007/s13593-016-0398-2 https://doi.org/10.1007/s13593-016-0398-2 
[43] Dou, T., Zhao, S., Rong, H., Gu, D., Li, Q., Huang, Y., Xu, Z., Chu, X., Tao, L., Liu, L., Ge, C., Marinus F.W. and Jia, J. (2017) Biological Mechanisms Discriminating Growth Rate and Adult Body Weight Phenotypes in Two Chinese Indigenous Chicken Breeds. BMC Genomics, 18, Article No. 469. https://doi.org/10.1186/s12864-017-3845-9

[44] Padhi, M.K. and Chatterjee, R.N. (2013) Carcass Quality Traits in Four Different Crossbreds Developed for Backyard Poultry and the Effect of Age on Carcass Quality under Intensive System of Rearing. Indian Journal of Animal Sciences, 83, 1102-1108.

[45] Katekhaye, A.F. (2017) Comparative Study on Carcass Characteristics of Shrinidhi and Vanaraja Chicken Varieties. Ph.D. Dissertation, P.V. Narsimha Rao Telangana Veterinary University, Rajendranagar, Hyderabad.

[46] Dalle, Z.A., Ricci, R., Cullere, M., Serva, L., Tenti, S. and Marchesini, G. (2020) Effect of Chicken Genotype and White Striping-Wooden Breast Condition on Breast Meat Proximate Composition and Amino Acid Profile: Research Note. Poultry Science, 99, 1797-1803. https://doi.org/10.1016/j.psj.2019.10.066

[47] Oblakova, M., Mincheva, N., Hristakieva, P., Ribarski, S., Penchev, I., Ivanova, I. and Lalev, M (2017) Evaluation of New Slow-Growing Chicken's Genotypes. II. Qualitative Meat Traits. Macedonian Journal of Animal Science, 7, 37-45.

[48] Choo, Y.-K., Oh, S.-T., Lee, K.-W., Kang, C.-W., Kim, H.-W., Kim, C.-J., Kim, E.-J., Kim, H.-S. and An, B.-K. (2014)The Growth Performance, Carcass Characteristics, and Meat Quality of Egg-Type Male Growing Chicken and White-Mini Broiler in Comparison with Commercial Broiler (Ross 308). Korean Journal of Food Science of Animal Resources, 34, 622-629. https://doi.org/10.5851/kosfa.2014.34.5.622

[49] Englmaierova, M., Skrivan, M., Taubner, T. and Skrivanova, V. (2020) Performance and Meat Quality of Dual-Purpose Cockerels of Dominant Genotype Reared on Pasture. Animals, 10, 387. https://www.researchgate.net/publication/339631072 https://doi.org/10.3390/ani10030387

[50] Gemechu, A. and Abiy, S. (2019) Economic Viability of Smallholder Dual Purpose Chickens and Pullet Farming Enterprises in Ethiopia. British Journal of Poultry Sciences, 8, 58-69. 